\title{
ЗАГАЛЬНІ ПОЛОЖЕННЯ ДІЯЛЬНОСТІ ВИЩОЇ КВАЛІФІКАЦІЙНОї КОМІСІї СУДДІВ В УКРАЇНІ В СУЧАСНИХ УМОВАХ
}

\author{
СІТНІКОВ Віталій Вадимович - аспірант кафедри адміністративного та \\ митного права Університету митної справи та фінансів \\ УДК $351.74: 342.922$ \\ https://orcid.org/0000-0002-4389-2710 \\ DOI 10.32782/LAW.2020.2.5
}

\begin{tabular}{|c|}
\hline 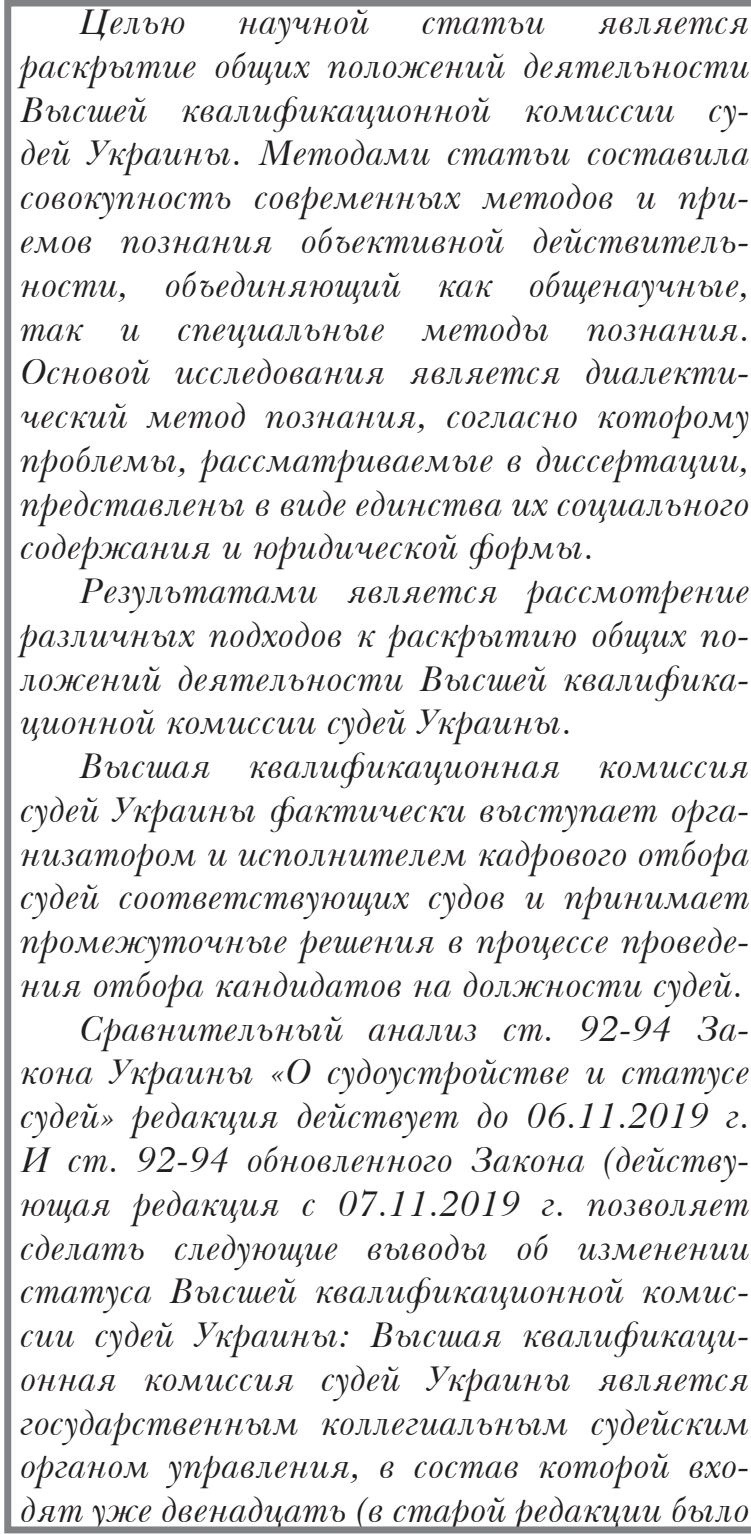 \\
\hline
\end{tabular}

шестнадиать) членов, которье назначаются взгсшим советом правосудия на 4 года по результатам конкурса. Член Вылсшей квалификационной комиссии судей Украинъ должен бътть политически нейтральнълм.

Ввсшая квалибикачионная комиссия судей Украинъ для осуществления своих полномочий имеет право истребовать и получать необходимую информаизию от судей, судов, Государственной судебной администрачии Украинъ, органов судейского самоуправления, инъгх органов и учреждений в системе правосудия, органов государственной власти и органов местного самоуправления, их должностных лии, предприятии, учреждений, организаиий независимо от бормв собственности и подчинения, объединений граждан и отдельньхх физических лич.

Ключевые слова: Высшая квалификачионная комиссия судей, обязанности, полномочия, права, судейский орган.

\section{Постановка проблеми}

У період набуття Україною ознак демократичної, соціальної, правової держави проблема кадрового забезпечення судової влади набуває особливого значення. У правовій державі суддям надається виключна роль, на відміну від інших гілок влади судова влада надається судді особисто [3].

У будь-якій країні завжди було актуальним питання здійснення правосуддя, а отже, і питання рівня кваліфікації суддів. Історично склалося, що в Україні ці питання були особливо яскраво вираже- 


\section{Адміністративне право}

ні, і тому зараз треба пильно приділяти увагу перевірці кваліфікації суддівського корпусу, іiі підтриманню i, що найголовніше, постійному підвищенню професійного рівня суддів.

\section{Огляд останніх досліджень та публікацій}

На сьогодні в науковій літератуpi практично відсутні дослідження, які грунтуються на оновленому законодавстві у сфері судоустрою та присвячені визначенню ролей ВККСУ в організації роботи судів.

Окремі аспекти діяльності ВККСУ досліджували такі вчені, як А. А. Борко, В. Д. Бринцев, О. В. Гончаренко, В. В. Долежан, Р. В. Ігонін, М. Г. Мельник, $\lambda$. М. Москвич, I. В. Назаров, Ю. Є. Полянський, О. М. Терлецький та багато інших [9].

Метою статті $\varepsilon$ розкриття загальних положень діяльності Вищої кваліфікаційної комісії суддів в Україні.

\section{Виклад основного матеріалу}

Вища кваліфікаційна комісія суддів України (далі - ВККСУ) - постійно діючий колегіальний орган у системі судоустрою України, відповідальний за формування суддівського корпусу, переведення суддів, забезпечення їх належного кваліфікаційного рівня [8].

У своїй діяльності Комісія керується Конституцією України, Законом, Регламентом ВККСУ та іншими нормативноправовими актами. Деталізація статусу, функцій та повноважень кваліфікаційної комісії передбачені Законом України (далі - 3У) «Про судоустрій і статус суддів» [8], а також Регламентом затвердженого рішенням ВККСУ від 13.10.2016 року № 81/3п$16[4]$.

У зв'язку з прийняттям Верховною Радою України ЗУ від 16 жовтня 2019 року № 193-IX «Про внесення змін до ЗУ «Про судоустрій і статус суддів»[4] та деяких законів України щодо діяльності органів суддівського врядування» повноваження нинішнього складу ВККСУ припиняють- ся. Президент підписав його 4 листопада, а 7 листопада він набув чинності. Встановлено, що з дня набрання чинності цим Законом, повноваження членів ВККСУ припиняються та запроваджується новий порядок формування їі нового складу, за яким призначення на посади 12 членів ВККС (кількість зменшено 316 членів) здійснюватиме ВРП за результатами конкурсу. Протягом дев'яносто днів 3 дня набрання чинності Закону, ВРП формує новий склад ВККСУ на підставі відкритого конкурсу. Члени ВККСУ призначаються та звільняються з посад за рішенням ВРП.

Основними засадами діяльності Комісії $\epsilon$ : верховенство права, законність, публічність, політична нейтральність, рівність прав учасників засідань, колегіальність ухвалення рішень, незалежність та неупередженість, об'єктивність, повне з'ясування обставин, обов'язковість рішень Комісії, право на оскарження рішень Комісії у передбачених Законом випадках [9].

Структура ВККСУ станом на вересень 2020 року [2]: 1) Секретаріат Вищої кваліфікаційної комісії суддів України;2) Служба інспекторів; 3) Сектор планування та організаційної роботи секретаріату Комісії; 4) Управління підготовки та проведення засідань Комісії; 5) Відділ підготовки засідань Комісії 6) Відділ проведення засідань, контролю та обліку рішень Комісії; 7) Департамент суддівської кар'єри; 8) Відділ по роботі з кандидатами на посаду судді; 9) Відділ з питань проведення перевірок; 10) Відділ методологічного забезпечення проведення іспиту; $11)$ Відділ ведення суддівського досьє; 12) Відділ організаційного забезпечення проведення іспиту; 13) Відділ забезпечення проведення регулярного оцінювання; 14) Відділ забезпечення організації переведень та конкурсу; 15) Відділ статистичноаналітичної роботи; 16) Управління документального забезпечення; 17) Відділ обліку та реєстрації справ (документів) палати з питань добору і публічної служби суддів; 18) Відділ опрацювання службової кореспонденції; 19) Відділ обліку та реєстрації справ (документів) кваліфікаційної палати; 
20) Сектор моніторингу виконання документів; 21) Сектор архівного діловодства; 22) Юридичне управління; 23) Відділ правової та нормотворчої роботи; 24) Відділ представництва інтересів Комісії в судах та інших органах влади; 25) Відділ по роботі 3 персоналом; 26) Фінансово-економічне управління; 27) Відділ бухгалтерського обліку та звітності; 28) Відділ планування, фінансового забезпечення та аналізу використання бюджетних коштів; 29) Управління інформаційних технологій; 30) Відділ технічного забезпечення; 31) Відділ супроводу програмного забезпечення;32) Сектор технічної обробки документів; 33) Відділ господарського та транспортного забезпечення; 34) Сектор договірних відносин та організації закупівель;35) Відділ міжнародного співробітництва; 36) Відділ видавничої діяльності та літературного редагування; 37) Сектор з питань доступу до публічної інформації, прийому та звернень громадян; 38) Сектор патронатної служби Голови Комісії [2].

У складі Комісії діє кваліфікаційна палата та палата з питань добору і публічної служби суддів. Голова Комісії та заступник Голови Комісії є головами цих палат. Комісія виконує функції та здійснює повноваження [6]: 1) у пленарному складі 3 таких питань: обрання Голови Комісії і заступника Голови Комісії, які є головами палат, та секретарів палат Комісії; звільнення члена Комісії з посади [8]; внесення подання щодо звільнення 3 посади члена Комісії [8]; ухвалення остаточного рішення по суті питання у випадку винесення на розгляд Головою Комісії у разі наявності окремої думки двох або більше членів палати Комісії, які брали участь у розгляді питання та ухваленні рішення відповідною палатою; організації діяльності Комісії, іï палат, колегій та секретаріату; $з$ інших питань, що стосуються всього складу Комісії, та у випадках, визначених Законом; 2) у складі кваліфікаційної палати з питань: проведення кваліфікаційного оцінювання; з інших питань за рішенням Комісії [6]; 3) у складі палати 3 питань добору і публічної служби суддів 3 питань: проведення добору кандидатів для призначення на посаду судді; внесення рекомендації про переведення судді відповідно до Закону, крім переведення як дисциплінарної санкції; з інших питань за рішенням Комісії [6]. Організаційне забезпечення діяльності Комісії здійснює секретаріат. Комісією можуть бути створені консультативні, дорадчі та інші допоміжні органи (ради, комісії, робочі групи тощо).

ВККС України є державним колегіальним органом суддівського врядування, який на постійній основі діє у системі правосуддя України. Вища кваліфікаційна комісія суддів $є$ постійно діючим колегіальним органом судової системи, основним призначенням яких є кадрове забезпечення суддівського корпусу в судах загальної юрисдикції, переведення суддів, забезпечення їх належного кваліфікаційного рівня. ВККСУ є юридичною особою, має печатку із зображенням Державного Герба України та своїм найменуванням, самостійний баланс та рахунки в органах Державної казначейської служби України [8].

Слід зазначити, що їх правовий статус зазнав суттєвих змін у зв'язку із впровадженням конституційної реформи 2015-2019 рр., через що наукові дослідження у цій сфері майже не проводилися.

Проведення в Україні чергової конституційної реформи призвело до внесення суттєвих змін до статусу основних органів кадрового забезпечення судів загальної юрисдикції - ВККСУ. Зокрема, в $3 У$ «Про внесення змін до Конституції України (щодо правосуддя)» [5] було враховано майже всі рекомендації, надані органами Ради Свропи (Парламентською Асамблеєю, Комітетом Міністрів, Свропейським судом 3 прав людини, Венеціанською комісією тощо) щодо провадження судової реформи в Україні.

7 листопада 2019 року набрав чинності оновлений $3 У$ «Про судоустрій і статус суддів» [4] редакція від 31.10.2019 р. Зокрема запроваджується новий порядок формування нового складу Вищої кваліфікаційної комісії суддів.

Статус Комісії визначається ЗУ «Про судоустрій і статус суддів» [8]. У ч. 1 ст. 92 оновленого закону України ВККСУ ви- 


\section{Адміністративне право}

знається державним колегіальним органом суддівського врядування, який на постійній основі діє в системі правосуддя України [8].

Не можна стверджувати, що таке законодавче формулювання є досконалим, однак із нього, принаймні, можна зробити деякі висновки. По-перше, ВКкСУ - це, передусім, державний колегіальний орган. По-друге, це орган судової влади й частина судової системи. По-третє, цей державний колегіальний орган покликаний здійснювати «суддівське врядування», що означає «управління», «розпорядження», «керівництво» [1, с. 76]. Застосування законодавцем поняття «суддівське врядування» є невипадковим, адже назвати ВККСУ органом суддівського самоврядування не можна, оскільки до їі основного складу входять не тільки судді, а й представники інших органів та організацій. При цьому цей орган здійснює лише частину управлінських функцій у судах.

Як правильно зауважує О. М. Терлецький, ВККСУ $є$ тим важливим органом у системі судоустрою держави, який безпосередньо формує судоустрій, готуючи професійних суддів і наглядаючи за порядком здійснення правосуддя [9]. Отже, ВККСУ $є$ одним з органів кадрового забезпечення суддівського корпусу судів.

Відповідно до ст. 94 ЗУ «Про судоустрій і статус суддів» до складу ВККСУ входять дванадцять членів, що призначаються Вищою радою правосуддя (далі - ВРП) за результатами конкурсу строком на чотири роки, які є громадянами України, мають повну вищу юридичну освіту і стаж професійної діяльності у сфері права не менше п'ятнадцяти років, належить до правничої професії та відповідає критерію політичної нейтральності [8].

Член ВККСУ не може належати до політичних партій, професійних спілок, брати участь у будь-якій політичній діяльності. За членом ВККСУ, який є суддею або державним службовцем, на час здійснення повноважень зберігаються посада, місце роботи та статус. Такі члени ВККСУ на час здійснення повноважень відряджаються до Комісії. Члени ВККСУ, які є адвоката- ми, на час виконання повноважень членів Комісії повинні зупинити адвокатську діяльність та участь в органах адвокатського самоврядування [6].

Член ВККСУ не має права суміщати свою посаду з будь-якою іншою посадою в органі державної влади або в місцевого самоврядування, органі суддівського, адвокатського або прокурорського самоврядування із статусом народного депутата України, депутата Верховної Ради Автономної Республіки Крим, обласної, районної, міської, районної у місті, сільської, селищної ради, 3 підприємницькою діяльністю, обіймати будь-яку іншу оплачувану посаду, виконувати іншу оплачувану роботу або отримувати іншу винагороду, окрім винагороди члена ВККСУ (за винятком здійснення викладацької, наукової чи творчої діяльності та отримання винагороди за неї), також входити до складу керівного органу чи наглядової ради юридичної особи, що має на меті одержання прибутку [6].

На членів ВККСУ поширюються вимоги та обмеження, встановлені законодавством у сфері запобігання корупції.

Особа, яка $є$ власником акцій або володіє іншими корпоративними правами чи має інші майнові права або інший майновий інтерес у діяльності будь-якої юридичної особи, що має на меті отримання прибутку, зобов'язана передати такі акції (корпоративні права) або інші відповідні права в управління незалежній третій особі (без права надання інструкцій такій особі щодо розпорядження такими акціями, корпоративними або іншими правами чи щодо реалізації прав, які з них виникають) на час перебування на посаді члена ВККСУ. Член ВККСУ може отримувати відсотки, дивіденди та інші пасивні доходи від майна, власником якого він є [6].

До складу ВККСУ не можуть бути призначені народні депутати України, члени Кабінету Міністрів України, голови судів, їх заступники, секретарі, голови судових палат, їх заступники, члени Ради суддів України, ВРП, Уповноважений Верховної Ради України з прав людини. До складу ВККСУ не можуть бути призначені осо- 
би, які притягалися до відповідальності за вчинення корупційного правопорушення [8].

Не можуть бути членами ВККСУ:1) особи, визнані судом недієздатними або обмежено дієздатними; 2) особи, які мають судимість, не погашену або не зняту в установленому законом порядку; 3) особи, на яких протягом останнього року накладалося адміністративне стягнення за вчинення правопорушення, пов'язаного 3 корупцією; 4) особи, які були членами ВККСУ або Вищої ради юстиції, ВРП; 5) особи, які обіймають адміністративні посади у судах; 6) особи, які не відповідають вимогам цього Закону щодо несумісності з іншими видами діяльності та не усунули таку невідповідність протягом розумного строку, але не більш як протягом тридцяти днів із дня виникнення обставин, які призводять до порушення вимог щодо несумісності [8].

Члени ВККСУ повинні у своїй діяльності та поза іï межами дотримуватися найвищих стандартів етичної поведінки, у тому числі принципів та правил етики, які застосовуються до суддів [9].

Перебування особи на посаді члена ВККСУ також несумісне із наявністю заборони такій особі обіймати посади, щодо яких здійснюється очищення влади в порядку, передбаченому Законом України «Про очищення влади» [5].

Відповідно до ст. 93 ЗУ «Про судоустрій і статус суддів» ВККСУ: 1) веде облік даних про кількість посад суддів у судах, у тому числі вакантних; 2) проводить добір кандидатів для призначення на посаду судді, у тому числі організовує проведення щодо них спеціальної перевірки відповідно до закону та приймає кваліфікаційний іспит; 3) вносить до ВРП рекомендацію про призначення кандидата на посаду судді; 4) вносить рекомендацію про переведення судді відповідно до цього Закону, крім переведення як дисциплінарної санкції; 5) визначає потреби у державному замовленні на професійну підготовку кандидатів на посаду судді у Національній школі суддів України; 6) затверджує за погодженням з ВРП форму і зміст заяви про участь у доборі кандидатів на посаду судді, анкети кандидата на посаду судді, порядок проходження спеціальної підготовки кандидатів на посаду судді; 6-1) розробляє та подає на затвердження ВРП проекти порядку складення відбіркового іспиту та методики оцінювання його результатів , порядку складення кваліфікаційного іспиту та методики оцінювання кандидатів, положення про проведення конкурсу на зайняття вакантної посади судді, порядку та методології кваліфікаційного оцінювання, порядку формування і ведення суддівського досьє (досьє кандидата на посаду судді); 7) проводить кваліфікаційне оцінювання; 8) забезпечує ведення суддівського досьє, досьє кандидата на посаду судді; 9) бере у межах компетенції участь у міжнародному співробітництві, у тому числі встановлює зв'язки з іноземними закладами, установами та організаціями, проектами міжнародної технічної допомоги, $є$ бенефіціаром, реципієнтом міжнародної технічної допомоги, головним розпорядником міжнародної допомоги від іноземних держав, банків і міжнародних фінансових організацій;10) здійснює інші повноваження, визначені законом [8].

ВККСУ для здійснення своїх повноважень має право витребувати та одержувати необхідну інформацію від суддів, судів, Державної судової адміністрації України, органів суддівського самоврядування, інших органів та установ у системі правосуддя, органів державної влади та органів місцевого самоврядування, їх посадових осіб, підприємств, установ, організацій незалежно від форми власності та підпорядкування, об'єднань громадян та окремих фізичних осіб. Ненадання такої інформації на вимогу Комісії має наслідком відповідальність, установлену законом. Члени та уповноважені працівники секретаріату ВККСУ мають безпосередній доступ до автоматизованих інформаційних і довідкових систем, реєстрів та банків даних, держателем (адміністратором) яких є державні органи або органи місцевого самоврядування, користуються державними, у тому числі урядовими, засобами зв'язку i комунікацій, мережами спеціального зв'язку та іншими технічними засобами. 


\section{Адміністративне право}

\section{АНОТАЦІЯ}

Метою наукової статті $є$ розкриття загальних положень діяльності Вищої квалібікаиійной комісіи суддів в Украйні. Методами статті склала сукупність сучасних методів $i$ прийомів пізнання об'єктивної дійсності, що поєднує як загальнонаукові, так $i$ спеціальні методи пізнання. Підгрунтям дослідження $\epsilon$ діалектичний метод пізнання, відповідно до якого проблеми, щзо розглядаються у дисертаияї, представлені у вигляді єдності їх соціального змісту та юридичної борми.

Результатами є розгляд різних підходів щодо розкриття загальних положень діяльності Вищзої квалібікаційної комісї суддів України.

Вища кваліфікаиійна комісія суддів Украӥни фактично виступає організатором $і$ виконавцем кадрового добору суддів відповідних судів та ухвалюе проміжні рішення в прощесі проведення добору кандидатів на посади суддів.

Порівняльний аналіз ст. 92-94 3У «Про судоустрій $i$ статус суддів» редакиія иинна до 06.11.2019 p. та cm.92-94 оновленого Закону (чинна редакція з 07.11.2019 р. дає підстави зробити такі висновки щодо зміни статусу Вищої кваліфбкачійної комісій суддів Украйни: Вища квалібікаиійна комісія суддів Украӥни $\epsilon$ державним колегіальним суддівським органом врядування, до складу якої входять вже дванадиять (в старій редакиій було шістнадиять) иленів, які призначаються вищою радою правосуддя на 4 роки за результатами конкурсу. Член Вищої квалібікаційної комісіи суддів України повинен бути політично нейтральним.

Вища квалібікаиійна комісія суддів України для здійснення своӥх повноважень має право витребувати та одержувати необхідну інформачію від суддів, судів, Державной судової адміністрації України, органів суддівського самоврядування, інших органів та установ у системі правосуддя, органів державної влади та органів місцевого самоврядування, їх посадових осіб, підприємств, установ, організаиій незалежно від борми власності та підпорядкування, об'єднань громадян та окремих ббізичних осіб.

Ключові слова: Вища квалібікаиійна комісія суддів,обов'язки, повноваження, права, суддівсъкий орган.

Обробка інформації здійснюється членами та уповноваженими працівниками Комісії iз дотриманням законодавства про захист персональних даних та забезпеченням таємниці, що охороняється законом. Доступ до інформації, що містить державну таємницю, здійснюється в порядку, встановленому законодавством про захист державної таємниці [6].

Порівняльний аналіз ст. 92-94 ЗУ «Про судоустрій і статус суддів» редакція чинна до 06.11.2019 р. та ст. 92-94 оновленого Закону (чинна редакція з 07.11.2019 р. [4].

\section{Висновки}

Отже, ВККСУ фактично виступає організатором і виконавцем кадрового добору суддів господарських судів та ухвалює проміжні рішення в процесі проведення добору кандидатів на посади суддів.

Порівняльний аналіз ст. 92-94 ЗУ «Про судоустрій і статус суддів» редакція чинна до 06.11.2019 р. та ст. 92-94 оновленого Закону (чинна редакція з 07.11.2019 р. дає підстави зробити такі висновки щодо зміни статусу ВККСУ: ВККСУ є державним колегіальним суддівським органом врядування, до складу якої входять вже дванадцять (у старій редакції було шістнадцять) членів, які призначаються ВРП на 4 роки за результатами конкурсу. Член ВККС України повинен бути політично нейтральним [4].

\section{Література}

1. Великий енциклопедичний юридичний словник / за ред. Ю. С. Шемшученка. Київ: Юрид. думка. 2012. С. 992.

2. Офіційний сайт Вищої кваліфікаційної комісії суддів України. URL: https://vkksu.gov.ua/ua/about/strukturasekretariatu-komisii/

3. Пивовар I. В. Статус кандидата на посаду судді України. Науковий вісник Міжнародного гуманітарного університету. Серія : Юриспруденція. 2014. Вип. 8. C. 51-54.

4. Про внесення змін до Закону України «Про судоустрій і статус суддів»: Закон України від 31.10.2019 р. № 193-IX.

5. Про внесення змін до Конституції України (щодо правосуддя): Закон Укра- 
їни від 02.06.2016 № 1401-VIII. Відомості Верховної Ради України. 2016. № 28. Ст. 532.

6. Про затвердження Регламенту Вищої кваліфікаційної комісії суддів України»: Регламент Вищої кваліфікаційної комісії суддів від 13.10. 2016 року N 81/зп-16.

7. Про очищення влади: Закон України від 16.09.2014 № 1682-VII. Відомості Верховної Ради України. 2014, № 44, ст.2041)

8. Про судоустрій і статус суддів: Закон України від 02.06.2016 № 1402-VIII. Відомості Верховної Ради України. 2016. № 31. Ст. 545.

9. Терлецький О. М. Вища кваліфікаційна комісія суддів та її роль в системі судоустрою // Матеріали III Міжнародної наукової Інтернет-конференції «Інновації та традиції в сучасній науковій думці». 2012.
The purpose of the scientific article is to reveal the general provisions of the High Qualification Commission of Judges in Ukraine. The methods of the article are a set of modern methods and techniques of cognition of objective reality, which combines both general and special methods of cognition. The basis of the study is a dialectical method of cognition, according to which the problems considered in the dissertation are presented in the form of unity of their social content and legal form.

The results are a review of different approaches to the disclosure of the general provisions of the High Qualifications Commission of Judges of Ukraine.

The High Qualification Commission of Judges of Ukraine actually acts as the organizer and executor of personnel selection of judges of the respective courts and makes interim decisions in the process of selection of candidates for judges.

Comparative analysis of Art. 92-94 of the Law "On the Judiciary and the Status of Judges", the wording is valid until November 6, 2019 and Art. 92-94 of the updated Law (the current version of November 7, 2019 gives grounds to draw the following conclusions on the change of status of the High Qualification Commission of Judges of Ukraine: The High Qualification Commission of Judges of Ukraine is a state collegial judicial governing body There were sixteen members who are appointed by the High Council of Justice for 4 years based on the results of the competition, and a member of the High Qualifications Commission of Judges of Ukraine must be politically neutral.

The High Qualifications Commission of Judges of Ukraine has the right to request and receive the necessary information from judges, courts, the State Judicial Administration of Ukraine, judicial self-government bodies, other bodies and institutions in the justice system, state authorities and local governments, their officials, enterprises, institutions, organizations, regardless of ownership and subordination, associations of citizens and individuals.

Keywords: High Qualification Commission of Judges, responsibilities, powers, rights, judicial body. 